\title{
Adopting a pedagogy of kindness
}

\author{
Alison Gilmour \\ The Open University
}

Keywords: compassion; trust; online and distance learning; embedding wellbeing; Covid19.

\section{The challenge}

Responding to the context of the Covid-19 pandemic, as an academic developer in a centralised learning and teaching unit and an associate lecturer in the social sciences, I understood that my students and I were plunged into a period of uncertainty, with many unknowns, disruption, and potential anxiety. The uniquely shared context intensified my focus on kindness as a pedagogical practice, with compassion shaping approaches to building equitable relationships and trust to support the 'circumstances under which learning could happen' (Denial, 2020, p. 213). This informed my approach as an academic developer supporting colleagues adapting to online learning, but also in 'walking the walk' as an associate lecturer at the UK's largest distance-learning university, The Open University.

Even for students anticipating studying through distance-learning, the pandemic presented challenges not to be underestimated. The university's supported distance model moved to fully online study with face-to-face classes cancelled. Awareness that the pandemic may compound the existing inequalities (Gilmour, 2020; 2021) experienced by widening participation students sharpened my focus on adopting a pedagogy of kindness (Denial, 2020), which manifested in a focus on fostering connection and nurturing a sense of agency and compassion amongst my students as we journeyed through the pandemic, as an approach to embedding wellbeing in the curriculum. Proponents of embedding wellbeing in the curriculum (Houghton and Anderson, 2017; Hughes and Spanner, 2019) recognise that responsibility for student wellbeing does not rest solely with dedicated student support expertise, but also with teachers, a critical and constant component of the 
student experience (Hughes, 2020). As the pandemic unfolded, I purposefully sought to support wellbeing through my pedagogical practice.

\section{The response}

\section{Connecting}

Seeking to narrow 'transactional distance' (Moore, 1997) and foster connection, rather than text-based communication between classes, I made greater use of video and audio, particularly in welcoming students, supporting a sense of cohort identity and belonging, and relating to my students. I wanted them to perceive me as approachable, and found it easier to humanise communications using audio and video. Colleagues commented that my enthusiasm in a welcome video, proactive motivational communications (Simpson, 2012) and 'good luck' messages before the final assignment, conveyed emotional support more overtly than text-only communication, some sharing with their students. I had students refer to such messages when contacting me.

\section{Co-constructing rather than 'telling'}

When setting expectations at the start of a module, I typically adopted an approach of 'telling' and seeking alignment with my expectations, rather than more openly exploring viewpoints, guided by equity and trust. A pedagogy of kindness recognises students as active classroom partners (Denial, 2020); therefore, I used the Mentimeter student response system to explore student viewpoints on forum discussions and netiquette, perspectives on staff and student contributions, and the shared responsibilities of all in this participatory space. This informed a staff and student co-owned 'Forum Netiquette' for asynchronous discussion forum participation. Similarly, I created a 'Stop, Start, Continue' (Danley, 2019) mid-module exercise in which students did not simply tell the teaching team their views, but reflected on their engagement, responsibilities and things they personally would stop, start and continue doing. The pandemic had the potential to create disconnection, so such opportunities to hear the student voice were important in building trust and supporting students to consider their agency. 


\section{Compassionate spaces}

It is important to create space for new social science students to explore challenging social issues, including divergent perspectives. The Mentimeter student response system was used pre-class to engage students with module content, but also to provide the opportunity to consider their agency in building a respectful classroom, what they would do to contribute and how they expected to be treated by others. Resulting discussions recognised different contexts from which students joined classes, expressions of empathy, and students assisting the participation of peers. For example, students became voluntary chat champions to ensure peers were heard regardless of mode of participation: I know that Niraj is not using the microphone but can I read his comment out for the group? In ways I had not experienced previously, student behaviour indicated an evolving sense of themselves as active agents in building a respectful and compassionate classroom aligned with Gilbert's (2017) concept of compassion-focused pedagogy and developing microcommunication skills of compassion, through which students notice and act on the distress of others or inequity.

\section{Normalising challenge}

To build classes as equitable and supportive spaces, I used role-modelling vulnerability and use of language to normalise challenge in learning, not least during a pandemic, and provided the space to say 'I don't know' or 'I'm finding this difficult'. All Mentimeter activities included options to anonymously select, I don't know. Using video and audio messages, I reflected openly on my learning challenges (writing my first essay, grappling with referencing, navigating a virtual learning environment). I also openly expressed finding the second UK lockdown difficult. This was modelling a very human experience normalising and demonstrating my openness to discussing and supporting others navigating challenges - and contributing to 'psychological safety' (Hughes, 2020).

\section{Recommendations}

The pandemic, and adopting a pedagogy of kindness, helped ascertain my sphere of influence in supporting wellbeing in the curriculum through relational approaches that foster connections, support participation, advocate compassion, and encourage my 
students as learners with agency. Student participation in online classes and pre-class polls was high, with greater in-class interaction between students, evidence of microcommunication skills of compassion, and more outside-of-class engagement with my students than in 12 years of teaching at the university.

Is this just being a good teacher? Perhaps, but the pandemic heightened my focus on wellbeing in ways that are fruitful for future practice. In taking a wellbeing lens on your teaching practice you may ask:

- How do you build connections with students at a distance, particularly at the start of a module?

- How do you support open staff and student co-construction, ensuring the student voice shapes the current module presentation?

- How do you model your experience of challenge - in learning or beyond?

- How do you develop student micro-communication skills of compassion?

A pedagogy of kindness is arguably more potent for learning developers, who do not have the continuity of working with students throughout a module and focused on fostering open learning environments, with students comfortable asking questions and exploring challenges.

- Consider using pre-session video or audio messages to humanise communications and foster approachability.

- With new students, co-constructing expectations or a class contract is a priority pre-class or in-class - and can encourage compassionate and respectful learning spaces beyond teacher-led expectations.

- All of this supports a space for exploring the navigation of challenge, strengthened by modelling your experiences to students. This can nurture approachability and possibly encourage students to request support in future or recommend it to peers. 


\section{References}

Danley, A. (2019) 'Using "start, stop, and continue" to gather student feedback to improve instruction', in deNoyelles, A., Albrecht, A., Bauer, S. and Wyatt, S. (eds.), Teaching Online Pedagogical Repository. Orlando, FL: University of Central Florida Center for Distributed Learning. Available at: https://topr.online.ucf.edu/using-start-stop-andcontinue-to-gather-student-feedback-to-improve-instruction/ (Accessed: 13 August 2021).

Denial, C. (2020) 'A pedagogy of kindness', in Stommel, J., Friend, C. and Morris, S.M. (eds.) Critical digital pedagogy: a collection. Washington. D.C.: Hybrid Pedagogy Inc, pp. 212-218.

Gilbert, T. (2017) 'When looking is allowed: what compassionate group work looks like in a UK university', in Gibbs, P. (ed.) The pedagogy of compassion at the heart of higher education. UK: Springer, pp. 189-202.

Gilmour, A. (2021) Let's talk about webcams, and a pedagogy of kindness', Compass: Journal of Learning and Teaching 14(2). Available at: https://doi.org/10.21100/compass.v14i2.1177 (Accessed: 12 August 2021).

Gilmour, A. (2020) 'An inclusive approach to the 'virtual campus' - keeping student experiences in focus', Greenwich Learning and Teaching Blog, University of Greenwich. Available at: https://blogs.gre.ac.uk/learningteaching/2020/03/30/inclusive-approach-to-the-virtual-campus/ (Accessed: 12 August 2021).

Houghton, A. and Anderson, J. (2017) Embedding Mental Wellbeing in the Curriculum: Maximising Success in Higher Education. York: Higher Education Academy. Available at: https://www.advance-he.ac.uk/knowledge-hub/embedding-mentalwellbeing-curriculum-maximising-success-higher-education (Accessed: 7 June 2021). 
Hughes, G. (2020) Supporting student wellbeing through curriculum design and delivery. Available at: https://ta.hw.ac.uk/wp-content/uploads/Guide-NO20 SupportingStudent-Wellbeing-Through-Curriculum-Design-and-Delivery.pdf (Accessed: 7 June 2021).

Hughes, G. and Spanner, L. (2019) The university mental health charter. Leeds: Student Minds. Available at:

https://www.studentminds.org.uk/uploads/3/7/8/4/3784584/191208 umhc artwork.p df (Accessed: 12 August 2021).

Moore, M. (1997) 'Theory of transactional distance', in Keegan, D. (ed.) Theoretical principles of distance education. New York: Routledge, pp. 22-38.

Simpson, O. (2012) Supporting students for success in online and distance education. $3^{\text {rd }}$ edn. New York: Routledge.

\section{Author details}

Alison Gilmour is an Associate Professor in Higher Education Learning and Teaching at the University of Greenwich and a part-time Associate Lecturer with The Open University. Her expertise is in the enhancement of teaching practice in blended learning contexts, supporting student engagement in dispersed learning communities, and embedding wellbeing in the curriculum. 